\begin{tabular}{l|c|c}
\hline ISSN: 0001-5113 & ACTA ADRIAT., & ORIGINAL SCIENTIFIC PAPER \\
AADRAY & $61(1): 57$ - 66, 2020 & \\
\hline
\end{tabular}

\title{
The diet of the anchovy Engraulis encrasicolus (Linnaeus, 1758) during the spawning season in the eastern Adriatic Sea
}

\author{
Bosiljka MUSTAĆ ${ }^{1}$ and Marijana HURE ${ }^{2 *}$ \\ ${ }^{1}$ Department of ecology, agronomy and aquaculture, University of Zadar, \\ Trg Kneza Višeslava 9, 23000 Zadar, Croatia \\ ${ }^{2}$ Institute for Marine and Coastal Research, University of Dubrovnik, \\ Kneza Damjana Jude 12, 20000 Dubrovnik, Croatia
}

*Corresponding author: marijana.hure@unidu.hr

The objective of this study was to determine, both quantitatively and qualitatively, the variability in the diet of the anchovy, Engraulis encrasicolus, during its spawning period. Samples were obtained from commercial purse seine catches (April 2014 - September 2016) from coastal and offshore fishing areas of different trophic states and zooplankton composition over the eastern Adriatic Sea. In general, decapod larvae comprise the main source of diet during the anchovies' spawning period in terms of frequency and abundance, followed by calanoid copepods. The main copepod prey that was identified for anchovy along the eastern Adriatic coast was calanoid Temora stylifera, followed by Oncaeid copepods and Corycaeidae. Although no significant differences in diet composition regarding the anchovy's size was observed, the contribution of copepods decreased in larger individuals, and were gradually substituted by large crustaceans - decapods, euphausiids, mysids and amphipods. However, a significant difference in prey composition between coastal and offshore areas was observed (global $R=0.164, p<0.05$ ). Beside adult copepods, offshore water anchovy fed mainly on decapod larvae and their megalopa stage, and amphipods. In the stomach of the fish caught in the coastal waters, higher contributions of euphausiids, mysids and fish eggs were observed. Prey diversity was greater in the stomach of specimens caught offshore $\left(H^{\prime}=0.59\right)$ than in the costal Adriatic waters $\left(H^{\prime}=0.40\right)$.

Key words: Small pelagic fish, trophic ecology, reproduction, Adriatic Sea

\section{INTRODUCTION}

Anchovy Engraulis encrasicolus (Linnaeus, 1758), together with other small pelagic fish, presents the most abundant species and is a commercially very important Mediterranean fishing resource (LLORET et al., 2004; SINOVČIĆ et al., 2009; MOROTE et al., 2010). Small pelagic fish account for more than $80 \%$ of the total annual catch in Croatian fisheries, being mostly caught by purse seine vessels.
However, small pelagic stocks are known for population fluctuations due to environmental variability and fishing, and therefore changes in their catches have been observed over recent decades (BAKUN, 1996; CINGOLANI et al., 2003; VAN BEVEREN et al., 2016). According to the General Fisheries Commission for the Mediterranean (GFCM), anchovy catches, as well as its spawning stock biomass, have declined during recent years in the Adriatic Sea and in some other areas of the Mediterranean (FAO, 2017). 
These fluctuations may cause changes in the pelagic trophic web. Moreover, exploitation of small pelagic fish can have important effects on the channelling of energy and on the structure of the food web, increasing vulnerability of populations to environmental variability (MORELLO \& ARNERI, 2009). Thus, the close relationship between the environment and small pelagic population dynamics demonstrates the need to increase the available data on feeding behaviour of small pelagic fish in relation to plankton dynamics and environmental factors (PALOMERA et al., 2007). In addition, there is a need for more comprehensive studies, including plankton surveys, for understanding completely the feeding behaviour of anchovy and the role of zooplanktonic groups in the diet of the species, as well as data on spatial variation of the relationship between small pelagic diet and mesozooplankton composition (BORME et al., 2009; AKALIN et al., 2019).

Data on anchovies' diet ecology have been reported from different parts of the Mediterranean (TUDELA \& PALOMERA, 1997; CONWAY et al., 1998; PLOUNEVEZ \& CHAMPALBERT, 2000; BORME et al., 2009; BACHA \& AMARA, 2009, MOROTE et al., 2010; CATALÁN et al., 2010; NIKOLIOUDAKIS et al., 2014; KARACHLE \& STERGIOU, 2014). However, studies on the feeding habits of this species from the eastern Adriatic Sea have been rare. An earlier paper reported on anchovy larvae feeding (REGNER, 1971), while only the study of ZORICA et al. (2016) has provided general information on adult anchovy feeding, considering ontogeny and seasonal patterns. Hence the objective of this study was to analyse, with respect to both ontogenetic and spatial variation, the diet of adult anchovy during its spawning season.

The location of pelagic fish is determined by the occurrence and persistence of their food, directly influencing fisheries (PITCHER, 1995). This survey was conducted in the spring-summer period corresponding to the anchovy's spawning season, and also to the main fishery period for this species in Croatia (SINOVČIĆ \& ZORICA, 2006). Hence our goal was to explore the quantitative and qualitative variability in the anchovy's diet during its spawning period, from areas (coastal and offshore fishing zones) of dif- ferent trophic states and zooplankton composition over the eastern Adriatic Sea.

\section{MATERIAL AND METHODS}

Anchovy specimens were collected from April 2014 to September 2016 (only during spring-summer months when it spawns in the Adriatic Sea), from commercial purse seine (mesh size $8 \mathrm{~mm}$ bar length) catches. In Croatia purse seine fisheries targeting small pelagic fish operate from sunset to sunrise using artificial light to attract and accumulate fish prior to harvest. Fig. 1 presents the Croatian fishing area which is administratively divided into 11 fishing zones. Specimens were caught both from the coastal (zones e and f), and the offshore fishing area (zones a, b, c and d).

In the laboratory, each fish was weighed to the nearest $0.01 \mathrm{~g}$ and measured to the nearest $\mathrm{mm}$. In total, 175 anchovies were analyzed for biometry, GSI and diet composition. After sex determination, gonads were removed from the fish and weighed. In addition, gonad development was also determined macroscopically by the shape and the structure of gonads according to an eight-stage scale, divided into four groups: immature (I and II), maturing (III and IV), mature (V and VI), spent (VII and VIII) (SINOVČIĆ \& ZORICA, 2006; MUSTAĆ \& SINOVČIĆ, 2012). Gonado-somatic index (GSI) was calculated by expressing each gonad mass as a proportion of the total body mass $(\mathrm{GSI}=100 \mathrm{Mg} / \mathrm{M}$, where $\mathrm{M}$ is total body mass and $\mathrm{Mg}$ is the gonad mass).

After biometry measures, the entire stomach of individual specimen was removed and fixed with ethanol (95\%). Stomachs were weighed before and after the prey items were carefully extracted. Dissection took place under a stereomicroscope and the entire stomach content of each fish was washed out on a Petri dish and examined individually (at 70 to $90 x$ magnification). Prey items were counted and identified to the lowest taxon possible. Also the proportion of each prey type in stomach content was estimated. To verify if any size-related food preference occurs in anchovy, specimens were grouped into three size classes $(<14 \mathrm{~cm}, 14-15 \mathrm{~cm}$ and $>15$ 


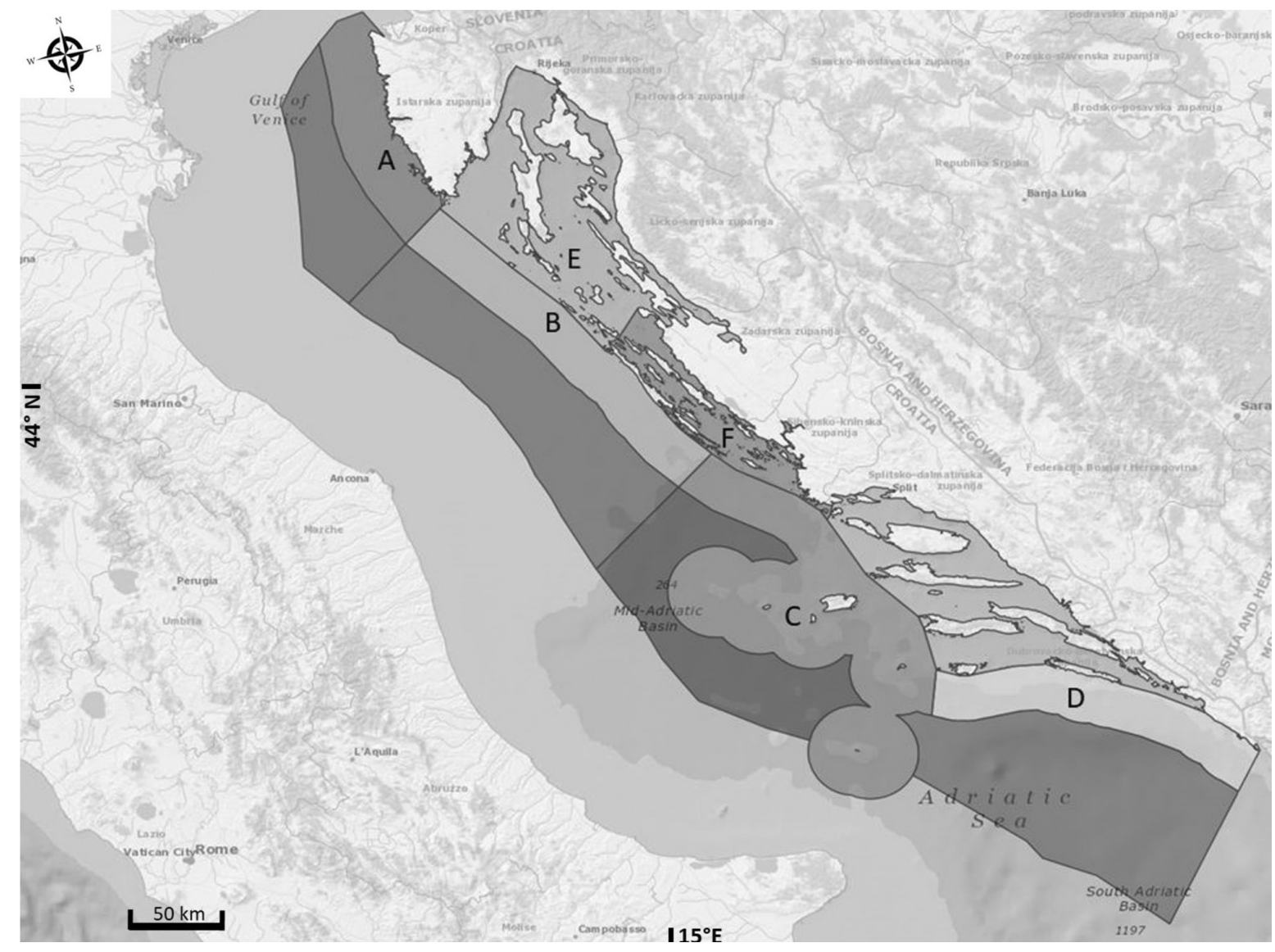

Fig. 1. Study area, fishing zones (A, B, C, D, E and F) in the eastern Adriatic Sea (Croatia)

$\mathrm{cm})$. Size classes were constructed according to the lengths of each monthly sample, as well as mean length $(14.47 \mathrm{~cm})$ and median length $(14.50 \mathrm{~cm})$ of the total sampled fish (Table 1).

Feeding incidence (FI) was calculated as the percentage of the total number of fish examined having at least one prey in the gut. The fullness index (\%Jr) (HUREAU, 1970) was calculated as: $\% \mathrm{Jr}=(\mathrm{Wp} / \mathrm{W}) \times 100$ where $\mathrm{Wp}$ is the mass of prey items calculated as the difference between the mass of an intact stomach and an empty stomach $\left(\mathrm{W}_{\mathrm{sf}}-\mathrm{W}_{\mathrm{se}}\right)$; $\mathrm{W}$ is total body mass.

The frequency of occurrence $(\% \mathrm{~F})$ (HUREAU, 1970) was calculated as: $\% \mathrm{~F}=\mathrm{n} / \mathrm{Nx} 100$, where $\mathrm{n}$ is the number of stomachs containing a certain prey and $\mathrm{N}$ is the total number of analysed stomachs containing any kind of prey.

The abundance $(\% \mathrm{~N})$ (BERG, 1979) was calculated as $\% \mathrm{~N}=\mathrm{np} / \mathrm{Np} \times 100$, where $n p$ is the number of prey items in a given taxon and $\mathrm{Np}$ is the number of all prey items.
Diversity of prey items in the diets was calculated using the Shannon-Wiener index H' (SHANNON \& WIENER, 1963), determined by the equation: $\mathrm{H}^{\prime}=-\Sigma \mathrm{i}$ pi $\log (\mathrm{pi})$, where pi is the proportion of the total count arising from the ith species.

Data on stomachs contents were $\log (\mathrm{x}+1)$ transformed and a Bray-Curtis similarity matrix was constructed. A one-way ANOSIM test was applied to explore the differences between zooplankton communities of different groups of samples (fish sizes and investigated sites) (CLARKE \& WARWICK, 1994). ANOSIM generates a test statistic, $\mathrm{R}$, and the magnitude of $\mathrm{R}$ is indicative of the degree of separation between groups, with a score of 1 indicating complete separation and 0 indicating no separation (CLARKE \& GREEN, 1988; CLARKE, 1993). The Shannon-Wiener diversity index and ANOSIM analysis were performed with the PRIMER 5 for Windows software suite (CLARKE \& GORLEY, 2001). 


\section{RESULTS}

\section{Length and reproduction population characteristics}

Anchovy total length ranged from 10.0 to $17.5 \mathrm{~cm}$ (mean \pm SD: $14.47 \pm 1.13 \mathrm{~cm}$ ) and mass from 5.93 to $33.88 \mathrm{~g}$ (mean $\pm \mathrm{SD}: 19.52 \pm 5.16$ $\mathrm{g})$. The largest anchovy samples were from April (mean \pm SD: $15.21 \pm 0.83 \mathrm{~cm}$ ), while the smallest ones were caught in September (mean $\pm \mathrm{SD}$ : $13.77 \pm 1.02$ ) (Table 1). The number of females was higher than males: we analysed 90 females and 78 males ( 7 were unidentified).

Regarding gonad maturation development, most of the samples had mature and spent gonads $(77.7 \%)$. Gonad mass $(\mathrm{Mg})$ was from 0.03 to $2.29 \mathrm{~g}$ (mean $\pm \mathrm{SD}: 0.63 \pm 0.45 \mathrm{~g})$, while gonado-somatic index (GSI) ranged from 0.26 to 7.83 (mean \pm SD: $3.03 \pm 1.73 \mathrm{~g}$ ).

\section{Fish size and spatial diet patterns}

Percentage of specimens with food in the stomach (FI) was $68.8 \%$. The fullness index (\%Jr) varied from $0.003 \%(\mathrm{TL}=16 \mathrm{~cm}, \mathrm{~W}=26.63$ g) to $7.053 \%(\mathrm{TL}=16.5 \mathrm{~cm}, \mathrm{~W}=32.39 \mathrm{~g})$ with generally higher values of $\% \mathrm{Jr}$ reported for larger specimens ( $\left.\mathrm{p}=0.0054 ; \mathrm{r}^{2}=0.0504\right)$ (Fig. 2). The average number of prey items ingested per fish was 14.41 (median 7; geometric mean 11) for the entire size range considered. The smallest anchovy individuals $(10.0-12.0 \mathrm{~cm})$ were found with empty stomachs.

Although the number of prey items slightly increased with fish size, there was no significant relationship between those two parameters

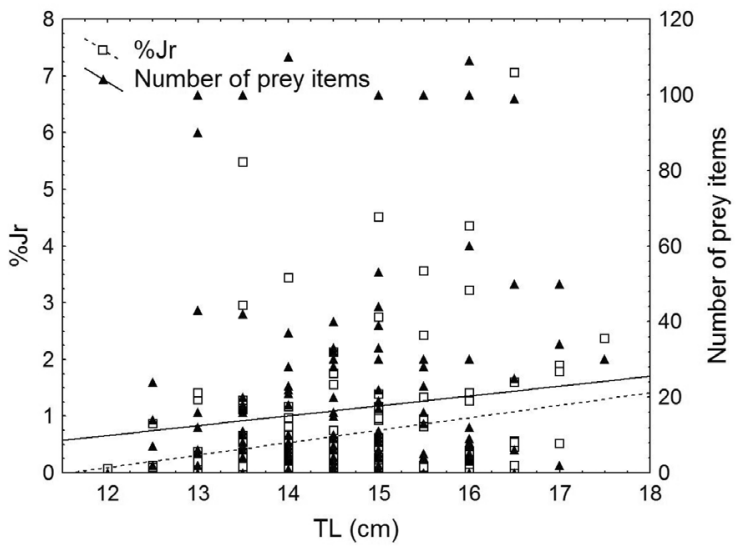

Fig. 2. Fullness index (\%Jr) and number of prey items per gut plotted against anchovy total length TL $(\mathrm{cm})$

$\left(p=0.1614 ; r^{2}=0.013\right)$. Feeding activity also varied over the different areas, as could be observed by the mean values of the fullness index $(\% \mathrm{Jr})$ displayed in Fig. 3; the highest values were recorded in the zones $\mathrm{c}$ and $\mathrm{d}$. In general, slightly higher $\% \mathrm{Jr}$ was observed in offshore fishing

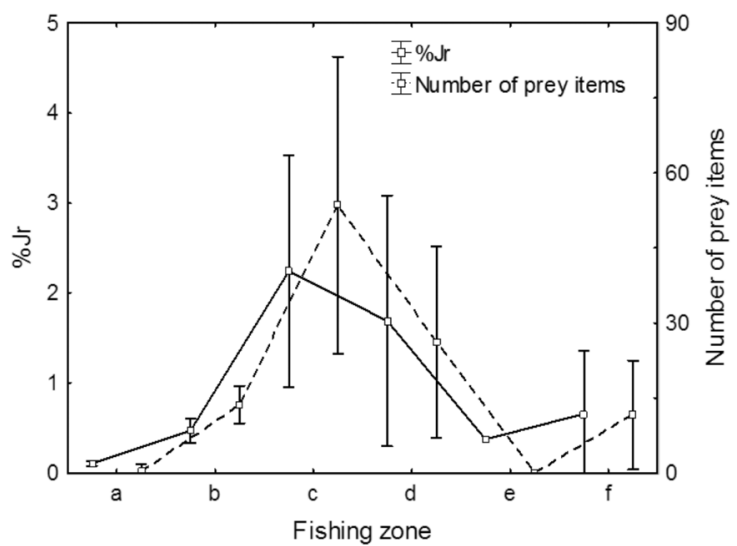

Fig. 3. Fullness index (\%Jr) and number of prey items per anchovy gut plotted against fishing zones

Table 1. Anchovy population characteristics (N-number of individuals, M/F-male female ratio, TL-total length in cm,

TW-total body weight in g, GSI-gonado-somatic index, \%Jr-fullness index), eastern Adriatic Sea, from April 2014 to September 2016

\begin{tabular}{lcccccc}
\hline Month & April & May & June & July & August & September \\
\hline $\mathrm{N}$ & 47 & 22 & 22 & 22 & 39 & 23 \\
$\mathrm{M} / \mathrm{F}$ & 1.04 & 0.57 & 0.47 & 0.69 & 1.29 & 0.44 \\
$\mathrm{TL}($ mean $\pm \mathrm{SD})$ & $15.21 \pm 0.83$ & $14.86 \pm 1.09$ & $14.18 \pm 1.14$ & $14.50 \pm 1.43$ & $13.89 \pm 0.74$ & $13.77 \pm 1.02$ \\
$\mathrm{TW}($ mean $\pm \mathrm{SD})$ & $22.72 \pm 3.72$ & $21.63 \pm 5.53$ & $18.70 \pm 5.30$ & $20.22 \pm 6.39$ & $16.75 \pm 3.37$ & $15.43 \pm 3.06$ \\
$\mathrm{GSI}($ mean $\pm \mathrm{SD})$ & $3.06 \pm 1.74$ & $4.31 \pm 1.76$ & $2.94 \pm 1.90$ & $3.20 \pm 1.66$ & $2.61 \pm 1.39$ & $0.93 \pm 0.78$ \\
$\% \mathrm{Jr}($ mean $\pm \mathrm{SD})$ & $0.47 \pm 0.55$ & $0.36 \pm 0.46$ & $1.16 \pm 1.72$ & $1.04 \pm 1.41$ & $0.52 \pm 0.99$ & $0.91 \pm 0.08$ \\
\hline
\end{tabular}


areas than in coastal zones $(0.662$ and 0.634 , respectively). Mean number of prey items over the different fishing zones showed similar patterns as the feeding activity, where the higher values were reported in zone c, and lowest in zones a and e. In addition, comparing coastal and offshore areas, average number of prey items in the offshore area was higher (17.14) than in the coastal one (10.69), although the difference was not significant (one-way ANOVA $\mathrm{p}=0.098, \mathrm{~F}=2.75$ ).

\section{Diet composition}

In the anchovies' stomachs, a total of 29 taxonomic groups were identified; their abundance and frequency of occurrence are reported in Table 2. Accordingly, decapod larvae, together with the megalopa stage, dominated in terms of frequency and abundance for the entire size range considered, followed by calanoid copepods. Amphipods, euphausiids and mysids were also numerous, while frequent occurrence was observed for amphipods and isopods. Among copepods, calanoids where consistently the most frequent prey mostly consisting of the species Temora stylifera together with small noncalanoids such as Oncaeid copepods and family Corycaeidae. Despite a high contribution of fish eggs in anchovies' diet, we did not observe any cannibalism. Finally, crustacean fragments and fish scales were found in $77.14 \%$ and $21.14 \%$ of specimens, respectively.

Considering the composition of prey groups in anchovies' diet, the smallest individuals fed mainly on decapod larvae and copepods (Fig. 4). Contribution of copepods decreased with fish size, while in larger specimens the proportion of euphausiids and mysids increased (up to $22 \%$ and $17 \%$, respectively). However, no significant differences in diet composition between anchovy sizes was observed (ANOSIM test, global $\mathrm{R}=0.047, \mathrm{p}>0.05$ ). Prey diversity was highest in smallest individuals $\left(H^{\prime}=0.62\right)$, while specimens over $15 \mathrm{~cm}$ had lowest average prey diversity $\left(H^{\prime}=0.48\right)$.

The ANOSIM test showed a significant difference in prey composition between coastal
Table 2. Frequency of occurrence $(\% F)$ and abundance $(\% N)$ of prey items found in stomachs of anchovy collected in the eastern Adriatic Sea, in spring-summer months from April 2014 to September 2016

\begin{tabular}{|c|c|c|}
\hline Prey items & $\% \mathrm{~F}$ & $\% \mathrm{~N}$ \\
\hline Protozoa & 0.8 & 0.10 \\
\hline Pteropoda unidentified & 7.38 & 0.71 \\
\hline Limacina trochiformis & 0.82 & 0.01 \\
\hline Cladocera Evadne spp. & 0.81 & 0.04 \\
\hline Copepoda calanoida unidentified & 52.46 & 31.66 \\
\hline Temora stylifera & 9.02 & 1.80 \\
\hline Calanus helgolandicus & 1.64 & 0.12 \\
\hline Clausocalanus spp. & 1.64 & 0.07 \\
\hline Scolecithrix bradyi & 0.82 & 0.02 \\
\hline Diaixis pygmaea & 0.82 & 0.02 \\
\hline Euchaetidae & 1.64 & 0.13 \\
\hline Oncaeid copepods & 3.28 & 0.63 \\
\hline Corycaeidae & 3.28 & 0.45 \\
\hline Macrosetella gracilis & 1.64 & 0.05 \\
\hline Goniopsyllus clausi & 0.82 & 0.04 \\
\hline Sapphirina spp. & 1.64 & 0.14 \\
\hline Copepoda unidentified & 3.28 & 0.39 \\
\hline Copepod eggs & 6.56 & 1.68 \\
\hline Amphipoda & 28.69 & 9.20 \\
\hline Isopoda & 19.67 & 3.51 \\
\hline Euphausiacea & 12.29 & 8.49 \\
\hline Mysida & 9.02 & 7.52 \\
\hline Ostracoda & 0.82 & 0.03 \\
\hline Decapod Larvae & 54.10 & 24.84 \\
\hline Decapod larvae - Megalopa stage & 25.41 & 6.85 \\
\hline Bivalvia larvae & 0.82 & 0.03 \\
\hline Cephalopoda Sepia spp. juvenile & 0.82 & 0.02 \\
\hline Fish larvae & 3.28 & 0.46 \\
\hline Fish egg & 9.84 & 3.69 \\
\hline
\end{tabular}

and offshore areas (global $\mathrm{R}=0.164, \mathrm{p}<0.05$ ). Besides adult copepods, offshore water anchovy fed mainly on decapods (25\%), amphipods (11\%) and megalopa stage of decapods (8\%). In the stomach of the fish caught in coastal waters, we found the highest contribution of decapods (31\%), followed by adult copepods (22\%), euphausiids (20\%) and fish eggs (14\%) (Fig. 5). Finally, prey diversity was greater in 


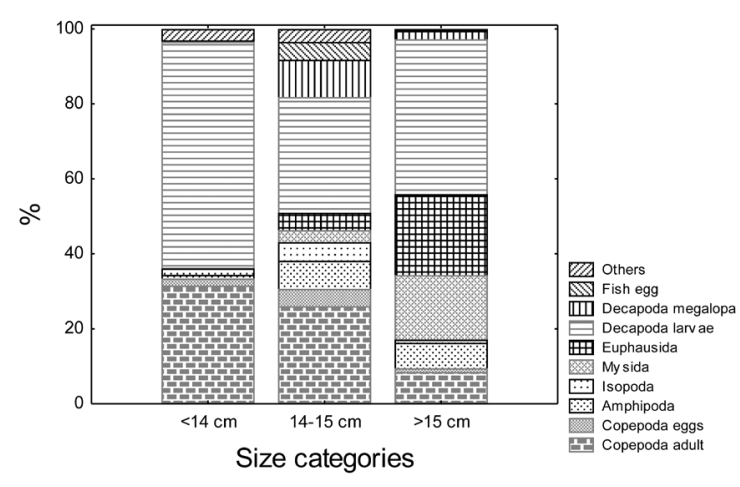

Fig. 4. Percentage of the main prey items of anchovy by its size categories

the stomach of specimens caught in offshore waters $\left(H^{\prime}=0.59\right)$ than in coastal Adriatic waters $\left(\mathrm{H}^{\prime}=0.40\right)$.

Since there are differences in zooplankton composition, abundances and biomass from the

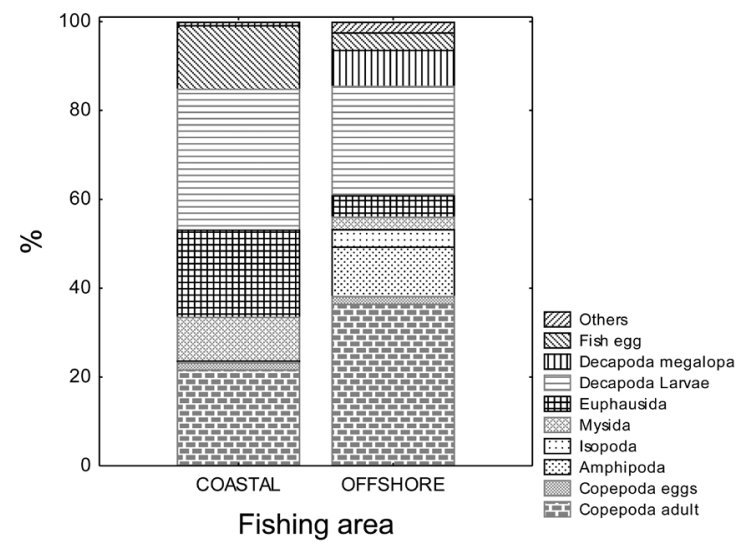

Fig. 5. Percentage of the main prey items of anchovy caught in coastal and offshore fishing area

northern to southern part of the Adriatic Sea (BENOVIĆ et al., 1985; FONDA UMANI, 1996), we analysed differences between each fishing zone included in our study. Spatial differences in diet composition showed moderate differences (ANOSIM, global $\mathrm{R}=0.121, \mathrm{p}>0.05$ ), the most pronounced difference in diet composition being observed between zones $\mathrm{c}$ and $\mathrm{d}$ (ANOSIM, $\mathrm{R}=$ 0.704, $\mathrm{p}<0.05$ ) and zones $\mathrm{c}$ and $\mathrm{f}$ (ANOSIM, $\mathrm{R}=0.552, \mathrm{p}<0.05$ ). Decapod larvae were the predominant prey both in terms of occurrence and number in anchovies' diet in zone c. Euphausiids were the most abundant prey in zone $d$ and mysids in zone $\mathrm{f}$, while decapod larvae were still the most numerous in term of occurrence $(71 \% \mathrm{~F}$ and $57 \% \mathrm{~F}$, respectively). The ANOSIM test, in both zones in term of occurrence, showed nonsignificant comparisons between other zones. The highest prey diversity was noted in zone $\mathrm{b}$ $\left(H^{\prime}=0.64\right)$, followed by zone $d\left(H^{\prime}=0.49\right)$.

\section{DISCUSSION}

Beside its great commercial significance, COLL et al. (2007) found anchovy to be the keystone species in the Adriatic ecosystem, considering total mixed trophic impacts of the food web. Although a significant number of studies on the feeding ecology of anchovy in the Mediterranean Sea have been conducted, relatively few of these studies addressed spatial variability in diet composition (BACHA \& AMARA, 2009). In the present study we present for the first time spatial variations in anchovy diet habits in the Adriatic Sea.

A mainly zooplanktivorous diet was reported for anchovy in most of the investigations carried out in the Mediterranean (KARACHLE \& STERGIOU, 2014; TUDELA \& PALOMERA, 1997; PLOUNEVEZ \& CHAMPALBERT, 2000; BORME et al., 2009, BACHA \& AMARA, 2009), which coincides with our study. The role of copepods (BACHA \& AMARA, 2009) and crustacean larvae (KARACHLE \& STERGIOU, 2014) has been emphasized in previous anchovy diet studies. Similar results were reported for the Adriatic Sea, where small copepods were observed as fundamental trophic link for this species in the north Adriatic (BORME et al., 2009). Copepods, together with decapod larvae, were the most abundant prey type in autumn and spring along the eastern Adriatic Sea (ZORICA et al., 2016).

In our study the main prey items found in stomachs were decapod larvae and copepods, while other items varied with size and area sampled.

Compared with ZORICA et al. (2016), we found a lower proportion of copepods in anchovy stomachs. A few possible reasons could explain this difference. Firstly, this can be related to fish size, since anchovies' mean and maximum lengths in the mentioned study were somewhat smaller than in our study. Secondly, feeding 
intensity, along with the quality of food consumed, appears to be strongly affected by the reproductive cycle and its energy demands (KARACHLE \& STERGIOU, 2014). Hence, anchovy use high energy food and increase their feeding intensity during the reproductive period in both zones. The dominance of decapod larvae (together with the megalopa stage) during our study could be associated with the higher energy needed for reproduction. Similar results were noted for this species on the Algerian coast (BACHA \& AMARA, 2009), and in Izmir Bay (AKALIN et al., 2019) where during the spawning period small copepods were gradually replaced by larger ones and larger prey. Finally, the scarce data available on decapod larvae from the southern Adriatic (HURE, 1955; LUČIĆ, 1998) indicate maximum abundances of this zooplankton group over the warmer part of the year, which coincides, with the spawning season of anchovy.

Other crustaceans (amphipods, euphausiids, isopods, mysids) were also important numerically with relatively high domination in terms of occurrence. That prey is characterized by high patchiness and could be important and abundant prey for anchovy.

The main copepod prey that was preferred by anchovy along the eastern Adriatic coast was the calanoid Temora stylifera, followed by Oncaeid copepods and Corycaeidae, which is in accordance with previous records (BACHA \& AMARA, 2009; TUDELA \& PALOMERA, 1995, 1997; PLOUNEVEZ \& CHAMPALBERT, 2000; BORME et al., 2009). BORME et al. (2009) showed feeding plasticity where anchovy is able to ingest bivalvia larvae during its high abundance in zooplankton composition, as well as cladocerans during the summer and appendicularians during the autumn (COSTALAGO et al., 2012). However, the contribution of those groups during our study was insignificant. This is probably due to zooplankton prey in the studied area. Anchovy has no need to compensate with energy rich prey (crustaceans) by including other zooplankton in their diet. Furthermore, in contrast to some areas where anchovy egg cannibalism is common, such feeding behaviour seems to be absent in the Mediterranean (TUDELA \& PALOMERA, 1997, BACHA \& AMARA, 2009, BORME et al., 2009, COS-
TALAGO et al., 2012) which was also confirmed in our study.

Although no significant diference in diet composition regarding fish size was observed, contributions of copepods decreased with anchovies' length, and were gradually substituted by large crustaceans such as decapods, euphausiids and mysids. In addition, ZORICA et al. (2016) reported no significant length, size or sex-related diet shifts in anchovy from the Adriatic Sea. BORME et al. (2009) also found that anchovy diet was similar between juveniles and adults in the northern Adriatic Sea.

During our study samples were taken from different productive areas of the Adriatic Sea. The central Adriatic, with depressions as deep as $280 \mathrm{~m}$, is a transition zone between the shallow, more productive, northern part, and relatively deep (up to $1270 \mathrm{~m}$ ) southern basin with oligotrophic characteristics (BULJAN, 1964). Thus, zooplankton standing stock generally decreases from the northern to southern part (FONDA UMANI, 1996; VUČETIĆ, 1971, 1979; BENOVIĆ et al., 1984). Mesozooplankton is generally dominated by copepods, especially in the open sea. This coincides with our findings; we observed a higher contribution of copepods in the anchovies caught in the offshore zones. Furthermore, waters surrounding the small island of Palagruža and Blitvenica (included in fishing zone c) are under the influence of a multitude of environmental parameters (topography and currents) and present an area more abundant in nutrients and planktonic organisms than the rest of the Central Adriatic (HURE \& KRŠINIĆ, 1998). Thus, this area has been known as the richest fishing ground in Croatia for centuries. Interestingly, stomachs of anchovy caught in this zone were fuller (both \% $\mathrm{Jr}$ and number of prey items) compared to the other Adriatic areas, but also notable differences in diet composition were found between fish caught in zone $\mathrm{c}$ and in the surrounding areas (zones d and f). Anchovy prey diversity corresponds with general zooplankton species richness in the Adriatic Sea, where higher values occur offshore than in the coastal parts.

Selectivity of particular food items could not be determined from this study, since ambient corresponding zooplankton samples were not 
available. Therefore, it would be interesting for future research to study simultaneously plankton composition and prey selectivity for anchovy, as well as for other small pelagic fish in the Adriatic Sea, including both adult fish and early life stages, as was already recommended by REGNER (1996).

\section{ACKNOWLEDGEMENTS}

This work is part of the ECOSEA project "Protection, improvement and integrated management of the sea environment and cross-border natural resources". We thank the members of the fishing association Omega 3, for their great support with fish samples. We are also very grateful for reviewers' comments, as well as to Mr. Steve Latham for English editing of the Manuscript.

\section{REFERENCES}

AKALIN, S., SEVER, T. M., D. ILHAM \& A. UNLUOGLU. 2019. The Diet Composition of European Anchovy, Engraulis encrasicolus (Linnaeus, 1758) in Izmir Bay, Aegean Sea. Turk. J. Fish.\& Aquat. Sci., 19 (5): 431-445.

BACHA, M. \& R. AMARA. 2009. Spatial, temporal and ontogenetic variation in diet of anchovy (Engraulis encrasicolus) on the Algerian coast (SW Mediterranean). Estuar. Coast. Shelf Sci., 85: 257-264.

BAKUN, A. 1996. Patterns in the Ocean. Ocean Processes and Marine Population Dynamics. California Sea Grant College System, San Diego, California, 323 pp.

BENOVIĆ, A., S. FONDA-UMANI, A. MALEJ \& M. SPECCHI. 1984. Net-zooplankton biomass of the Adriatic Sea. Mar. Biol., 79 (2): 209-218. BERG, J.1979. Discussion of methods of investigating the food of fishes, with reference to a preliminary study of the prey of Gobiusculus flavescens (Gobiidae). Mar. Biol., 50: 263273.

BORME, D., TIRELLI, V., BRANDT, S. B., S. FONDA UMANI \& E. ARNERI. 2009. Diet of Engraulis encrasicolus in the northern Adriatic Sea (Mediterranean): ontogenetic changes and feeding selectivity. Mar. Ecol. Prog. Ser., 392: 193-209.

BULJAN, M. 1964. Ocjena produktivnosti Jadrana dobivena na temelju njegovih hidrografskih svojstava. Acta Adriat., 11: 35-45.

CATALÁN, A. C., A. FOLKVORD, I. PALOMERA, E. QUÍLEZ-BADÍA, F. KALLIANOTI, A. TSELEPIDES \& A. KALLIANOTIS. 2010. Growth and feeding patterns of European anchovy (Engraulis encrasicolus) early life stages in the Aegean Sea (NE Mediterranean). Estuar. Coast. Shelf Sci., 86: 299-312.

CINGOLANI, N., T. KARIŠ, G. SINOVČIĆ \& E. KAPEDANI. 2003. Sardine (Sardina pilchardus, Walb.) stock assessment in the Adriatic Sea: 1975-2002. In: Mannini, P., F. Massa \& N. Milone (Editors). AdriaMed Occasional Papers, 1, pp. 1-11.

CLARKE, K R. 1993. Non-parametric multivariate analyses of changes in community structure. Aust. J. Ecol., 18: 117-143.

CLARKE, K.R. \& R.H.GREEN. 1988. Statistical design and analysis for a 'biological effects' study. Mar. Ecol. Prog. Ser., 46: 213-226.

CLARKE, K. R. \& R.M. WARWICK. 1994. Similaritybased testing for community pattern: the 2-way layout with no replication. Mar. Biol., 118: 167-176.

CLARKE, K. R. \& R. GORLEY. 2001. PRIMER v5. User Manual/Tutorial.Plymouth, UK: PRIMER-E Ltd, pp. 91.

COLL, M., A. SANTOJANNI, I. PALOMERA, S. TUDELA \& E. ARNERI. 2007. An ecological model of the Northern and Central Adriatic Sea: analysis of ecosystem structure and fishing impacts. J. Mar. Sys., 67: 119-154.

CONWAY, D.V.P., H. COOMBS \& C. SSMITH. 1998. Feeding of anchovy Engraulis encrasicolus larvae in the North Western Adriatic Sea in response to changing hydrobiological conditions. Mar. Ecol. Prog. Ser., 175: 35-49.

COSTALAGO, D., J. NAVARRO, I. ÁlVAREZ-CALlE- 
JA \& I. PALOMERA. 2012. Ontogenetic and seasonal changes in the feeding habits and trophic levels of two small pelagic fish species. Mar. Ecol. Prog. Ser., 460: 169-181.

FAO, 2017. GFCM, Scientific Advisory Committee on Fisheries (SAC) Working Group on Stock Assessment of Small Pelagic species (WGSASP) FAO HQ, Rome, Italy, pp. 66.

FONDA UMANI, S. 1996. Pelagic production and biomass in the Adriatic Sea. Sci Mar., 60 (2): 65-77.

HURE, J. 1955. Distribution annuelle verticale du zooplancton sur une station de l'Adriatique méridionale. Acta Adriat., 7: 1-72.

HURE, J. \& F. KRŠINIĆ. 1998. Planktonic copepods of the Adriatic Sea. Spatial and temporal distribution. Natura Croatica: periodicum Musei historiae naturalis Croatici, pp.135.

HURE, M. \& B. MUSTAĆ. 2020. Feeding ecology of Sardina pilchardus considering co-occurring small pelagic fish in the eastern Adriatic Sea. Mar. Biodivers., 50: 40.

HUREAU, J. C. 1970. Biologie comparée de quelques poissonsantarctiques (Nototheniidae). Bulletin de l'Institut océanographique de Monaco, 68, pp. 244.

KARACHLE, P. K. \& K.I. STERGIOU. 2014. Feeding and ecomorphology of three clupeoids in the North Aegean Sea. Med. Mar. Sci., 15(1): 9-26.

LLORET, J., I. PALOMERA, J. SALAT \& I. SOLE. 2004. Impact of freshwater input and wind on landings of anchovy (Engraulis encrasicolus) and sardine (Sardina pilchardus) in shelf waters surrounding the Ebre (Ebro) River delta (north-western Mediterranean. Fish. Oceanogr., 13 (2): 102-110.

LUČIĆ, D. 1998. Annual variability of the decapod larvae community in the shallow waters of the southern Adriatic. Acta Adriat., 39(1): 25-30.

MOROTE, E., M.P. OLIVAR, F. VILLATE \& I. URIARTE. 2010. A comparison of anchovy (Engraulis encrasicolus) and sardine (Sardina pilchardus) larvae feeding in the Northwest Mediterranean: influence of prey availability and ontogeny. ICES J. Mar. Sci., 67: 897-908.

MUSTAĆ, B. \& G. SINOVČIĆ. 2012. Reproductive cycle of gilt sardine, Sardinella aurita, in the eastern middle Adriatic Sea. J. Appl. Ichthyol. 28: 46-50.

NIKOLIOUDAKIS, N., S. ISARI \& S. SOMARAKIS. 2014. Trophodynamics of anchovy in a nonupwelling system: direct comparison with sardine. Mar. Ecol. Prog. Ser., 500: 215-229.

PALOMERA, I., M. P. OLIVAR, J. SALAT, A. SABATES, M. COLL, A. GARCÍA \& B. MORALES-NIN. 2007. Small pelagic fish in the NW Mediterranean Sea: an ecological review. Prog. Oceanogr., 74: 377-396.

MORELLO, E.B. \& E. ARNERI. 2009. Anchovy and Sardine in the Adriatic Sea - An Ecological Review. Oceanogr. Mar. Biol., 47: 46-50.

PITCHER, T.J. 1995. The impact of pelagic fish behaviour on fisheries. Sci. Mar., 59(3-4): 295-306.

PLOUNEVEZ, S. \& G. CHAMPALBERT. 2000. Diet, feeding behaviour and trophic activity of the anchovy (Engraulis encrasicolus L.) in the gulf of lion (Mediterranean Sea). Oceanol. Acta, 23: 175-192.

REGNER, S. 1971. Prilog poznavanju ishrane postlarava brgljuna, Engraulis encrasicolus (Linnaeus, 1758), u srednjem Jadranu. Ekologija, 6: 157-164.

REGNER, S. 1996. Effects of environmental changes on early stages and reproduction of anchovy in the Adriatic Sea. Sci. Mar., 60: 167-177.

SHANNON, C. E. \& W. WIENER. 1963. The Mathematical theory of communication. University of Juionis Press, Urbana., pp.117.

SINOVČIĆ, G. \& B. ZORICA. 2006. Reproductive cycle and minimal length at sexual maturity of Engraulis encrasicolus (L.) in the Zrmanja River estuary (Adriatic Sea, Croatia). Estuar. Coast. Shelf Sci., 69 (3-4): 439-448.

SINOVČIĆ, G., B. ZORICA, V. ČIKEŠ KEĆ \& B. MUSTAĆ. 2009. Inter-annual fluctuations of the population structure, condition, lengthweight relationship and abundance of sardine, Sardina pilchardus (Walb., 1792), in the nursery and spawning ground (coastal and open sea waters) of the eastern Adriatic Sea (Croatia). Acta Adriat., 51(1): 11-22.

TUDELA, S. \& I. PALOMERA. 1995. Diel feeding intensity and daily ration in the anchovy Engraulis encrasicolus in the northwest 
Mediterranean Sea during the spawning period. Mar. Ecol. Prog. Ser., 129: 55-61.

TUDELA, S. \& I. PALOMERA. 1997. Trophic ecology of the European anchovy Engraulis encrasicolus in the Catalan Sea (northwest Mediterranean). Mar. Ecol. Prog. Ser., 160: 121-134.

VAN BEVEREN, E., J.M. FROMENTIN, T. ROUYER, S. BONHOMMEAU, P. BROSSET \& C. SARAUX. 2016. The fisheries history of small pelagics in the Northern Mediterranean. ICES J. Mar. Sci., 73 (6): 1474-1484.
VUČETIĆ, T. 1971. Long-term zooplankton standing crop fluctuations in the Central Adriatic coastal region. Thalassia Jugoslavica., 7: 419-428.

VUČETIĆ, T. 1979. Dugoročna istraživanja planktona na području otoka Hvara. Acta biologica, Prirodoslovna istraživanja, 43: 99-113.

ZORICA, B., V. ČIKEŠ KEČ, O. VIDJAK, I. MLADINEO, \& D. EZGETA BALIĆ. 2016. Feeding habits and helminth parasites of sardine (S. Pilchardus) and anchovy (E. Encrasicolus) in the Adriatic Sea. Med. Mar. Sci., 17(1): 216-229.

Received: 13 December 2019

Accepted: 11 February 2020

\title{
Prehrana brgljuna Engraulis encrasicolus (Linnaeus, 1758) tijekom mrijesta u istočnom dijelu Jadranskoga mora
}

\author{
Bosiljka MUSTAĆ i Marijana HURE* \\ *Kontakt e-pošta: marijana.hure@unidu.hr
}

\section{SAŽETAK}

Cilj ovog rada bio je utvrditi kvantitativnu i kvalitativnu varijabilnost u prehrani brgljuna Engraulis encrasicolus tijekom mrijesta. Uzorci iz komercijalnih ulova plivaricom (travanj 2014 rujan 2016), obuhvatili su ribolovna područja obalnog i otvorenog mora duž istočne obale Jadrana, različitog trofičkog stanja i sastava zooplanktona. Ličinke deseteronožaca općenito su glavni izvor hrane tijekom mrijesta brgljuna, a prate ih kalanoidni veslonošci.

Unutar veslonožaca najzastupljenija je bila vrsta kalanoida Temora stylifera, a slijede veslonošci skupine Oncaea i porodica Corycaeidae. Premda nisu utvrđene značajne razlike u sastavu prehrane u odnosu na dužinu ribe, udio veslonožaca smanjio se porastom dužine brgljuna, a postupno su ih nadomještali veliki rakovi - deseteronošci, eufazidi, rašljonožci i rakušci.

Međutim, uočena je značajna razlika u sastavu plijena između obalnog i otvorenog mora (globalni $\mathrm{R}=0.164, \mathrm{p}<0.05$ ). Pored odraslih veslonožaca, brgljun otvorenog mora hranio se uglavnom ličinkama deseteronožaca i njihovih megalopa stadija te rakušci. U želucu ribe ulovljene u obalnim vodama primijećen je veći doprinos eufauzida, rakušcima i ribljih jaja. Raznolikost plijena bila je veća u želucima jedinki ulovljenih u otvorenim vodama $\left(\mathrm{H}^{\prime}=0.59\right)$ nego u obalnom dijelu Jadrana $\left(H^{\prime}=0.40\right)$.

Ključne riječi: sitna plava riba, trofička ekologija, razmnožavanje, Jadransko more 